\title{
Impact of long term nutrient management on soil fertility determinants and performance of rice in terraced land
}

MANOJ DUTTAAND AKUMMENLALONGCHER

\author{
MEMBERS OF RESEARCH FORUM \\ Corresponding author : \\ MANOJ DUTTA, Department of Soil \\ and Water Conservation, School of \\ Agricultural Sciences and Rural \\ Development, Nagaland University, \\ Medziphema Campus, MEDZIPHEMA \\ (NAGALAND) INDIA \\ Email: manojdutta1997@yahoo.com
}

Co-authors :

AKUMMENLA LONGCHER

Department of Soil and Water Conservation, School of Agricultural Sciences and Rural Development, Nagaland University, Medziphema Campus, MEDZIPHEMA (NAGALAND) INDIA
Received : 10.12.2014; Revised : 23.04.2015; Accepted : 01.05 .2015

\begin{abstract}
Summary
The impact of long term nutrient management practices on soil fertility determinants and performance of upland rice after thirteen years of continuous cultivation on terraced land were studied in a field experiment conducted on the experimental farm of the School of Agricultural Sciences and Rural Development under rainfed conditions. Twelve treatments involving N, P and K (NPK) fertilizers, FYM, poultry litter, forest litter, Azospirillum and Zn either alone or in combinations were applied for thirteen years and rice crop cultivated continuously. The organic $\mathrm{C}$ content, available $\mathrm{N}, \mathrm{P}$ and $\mathrm{K}$, number of productive tillers, grain and straw yield increased significantly in all the treatments. The highest accumulation of available $\mathrm{N}, \mathrm{P}$ and $\mathrm{K}$ was observed in NPK+ poultry litter, NPK+ FYM and $1 / 2 \mathrm{~N}+\mathrm{PK}+1 / 2 \mathrm{~N}$ forest litter treatments, respectively. After thirteen years the rate of build up of available $\mathrm{N}, \mathrm{P}$ and $\mathrm{K}$ in different nutrient management practices ranged from 5.2 to $16.9,0.33$ to 0.80 , and 1.96 to $7.03 \mathrm{ha}^{-1} \mathrm{yr}^{-1}$, respectively. Addition of FYM and poultry litter with NPK increased 28.7 and 25.9 per cent in grain yield and 50.3 and 49.4 per cent in straw yield, respectively as compared to NPK alone.
\end{abstract}

Key words : Soil fertility determinants, Rice yield, Terraced land

How to cite this article : Dutta, Manoj and Longcher, Akummenla (2015). Impact of long term nutrient management on soil fertility determinants and performance of rice in terraced land. Asian J. Soil Sci., 10(1) : 80-86. 